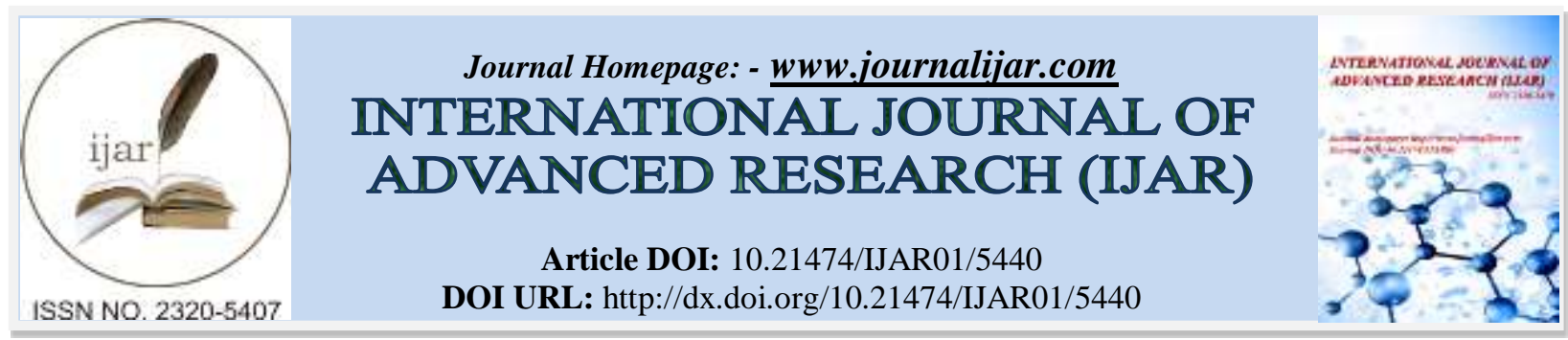

RESEARCH ARTICLE

\title{
A STUDY OF MORBIDITY PATTERN AND HEALTH SEEKING BEHAVIOUR IN URBAN SLUM POPULATION OF VARANASI, INDIA.
}

\author{
Sarvesh Kumar ${ }^{1}$ and Neha Mishra ${ }^{2}$. \\ 1. Department of OBGYN, S. N. Medical College, Agra. \\ 2. Department of Statistics, University of Lucknow.
}

\section{Manuscript Info}

Manuscript History

Received: 16 July 2017

Final Accepted: 18 August 2017

Published: September 2017

Key words:-

Morbidity, Health, Health seeking

Behaviour, Urban slums.

\begin{abstract}
Background \& Objectives: Health is an essential part for good quality of life. India provides unbounded range of wide geographic variations, besides cultural differences, so level of health and disease vary between people and place overtime. Healthcare seeking behavior is any activity undertaken by individuals who perceive they to have a health problem or to be ill for the purpose of finding an appropriate remedy keeping this view the aim of this study is to estimate the burden of regular disease and the associated spectrum of morbidities in different urban slums of Varanasi district, Uttar Pradesh.

Methods: A descriptive cross-sectional study was conducted to find out the morbidity pattern and health seeking behavior of urban slums in some selected urban slums areas of Varanasi City. We had selected randomly 7 slums out of 218 urban slums for this study. Total 600 household surveyed from the urban slums area from the Varanasi. Complete information has been collected on complete enumeration basis through pre designed and pre-tested questionnaires.

Result: out of 600 household majority of the respondents, 494(25.7\%) were male and 604(33.4\%) were female belonging to 15-29 age group. The dominance of religion in the study subjects was in the following sequence of 569 (94.8\%) Hindu and 31(5.16\%) Muslims. Majority of households respondents 516(86\%) found to be married followed by $84(14 \%)$ widow respondents. Regarding educational status, 265 (44.16\%) were illiterate and 335(56.7\%) were literate. Most 222(37\%) of the respondents were employed like daily wages, own business $149(24.83 \%)$, private jobs $65(13.83 \%)$ and not working respondents was $87(14.5 \%)$.Majority $559(93.17 \%)$ of the slum dwellers consulted government hospitals 225(40.25) a private hospitals 334(59.75\%) during illness. Among 200(33.3\%) respondents preferred to visit private hospitals $141(70.50 \%)$ for the consulted viral and cough cold rest of the going government medical college during to illness. Highly significant difference was found between the education and occupation of the urban slums respondents with gender of the household. $(\mathrm{p}=0.001$ and $\mathrm{p}=0.01)$ and significant association was found occupation of the urban slums respondents with health seeking behaviour during illness $(\mathrm{p}=0.0418)$. According to findings utilization of health care facilities urb an slums $13.6 \%$ of cases are of pregnancy goes to
\end{abstract}


government medical college and $16.8 \%$ were availed the treatment from the private hospital. Cases of Viral \& cold cough were taken the treatment of government facilities $30.9 \%$. No case found of pneumonia goes to private hospitals in Binayaka, Chitaipur, Navabganj, Ranipur \& Tulsipur.

Copy Right, IJAR, 2017,. All rights reserved.

\section{Introduction:-}

The concept of slums and their definition vary considerably across the states depending upon the socio-economic conditions or local perceptions prevailing in the society. There are regional differences in the names by which these slums are known in India. In Delhi, slums are commonly called 'Jhuggi-Jhonpari', whereas in Mumbai 'Jhopadpatti' or 'Chawls' are the names for slums, it is 'Ahatas' in Kanpur, 'Bustees' in Kolkata, 'Cheris' in Chennai and 'Keris' in Bangalore. But physical characteristics in most of these slums are essentially the same. They are usually a cluster of hutments with dilapidated and infirm structures having common toilet facilities, suffering from lack of basic amenities, inadequate arrangement for drainage and for disposal of solid assets and garbage ${ }^{1}$. In recent years, the rapid growth of slum in India cities has created interest in the policy makers as it has emerged as a major social and public health problem. The slum population constitutes about 23 per cent of the total urban population and has been alarmingly ballooning (Registrar General of India, 2011) ${ }^{2}$.The need for formulation of appropriate policy and proper implementation thereof for rapid improvement of health in the cities, especially in the slums of the cities, is urgent. That in turn requires information and evidence about the constraints on both demand and supply sides of healthcare use in the urban slums. Morbidity may be defined as the attributes of sickness like illness, disability, handicap and other compromised states of physical, social and mental well-being. Self-perceived morbidity refers to measures that are perceived and reported by an individual in response to inquiries regarding illness or symptoms over a defined time period ${ }^{3}$. To understand the morbidity Pattern and healthcare seeking behavior in different kind of socioeconomic class of the community is important for planning and delivery of appropriate health services, especially for the poor. ${ }^{4}$ This most common form of morbidity data in the developing world may be biased by factors like individual knowledge and experience, personal predisposition in the perception of illness and its social acceptance, somatization and conscious misreporting of illness to achieve other goals. To characterize a full range of morbidity, measuring both self-perceived and observed Morbidity is advocated ${ }^{5}$. The slum is almost ignored by the government in terms of providing health-care facilities and NGOs providing such services are almost rare. Thus, the urban slums were selected as the ideal area for the study ${ }^{6}$. Very few researches have been undertaken on health care demand in developing countries, and even less that focuses on the poor, especially the urban poor. A recent study on the demand for Health Care among urban slum residents in Varanasi, Uttar Pradesh concluded that urban health systems in Uttar Pradesh must work to improve access to care by the poor. The present study might be interesting for health planners and other relevant stakeholders in developing states as they need to understand people's healthcare utilization pattern including determinants of leading healthcare services. Evidence from this study also indicates that the urban poor view health care as both an investment in future productivity and as consumption good. Hence, providing health care facilities to the urban slum people of Varanasi in balancing social welfare. This information also helps in formulating policies and implementing targeted strategies which are responsive to urban slums people's needs and their priorities the main objectives of the study was to examine the pattern of morbidity, illness and health care seeking behaviour in the study subjects.

\section{Materials and Methods:-}

The present study was conducted in urban slums of Varanasi with objectives of assessing the Morbidity Pattern and Health seeking behaviour of study population. A cross sectional survey was carried out in randomly selected urban slums of Varanasi out of total 218 urban slums named as Badi Gaibi, Binayaka, Chitaipur, Karaundi, Navabganj, Ranipur and Tulsipur. Urban slums were collected through the cluster random sampling method. Assurance has been given to the respondents that the confidentiality concerning their information would be maintained strictly. A semi structured pre-tested questionnaire was developed to collect data from a face-to-face interview of a total 600 households. The data were checked, verified and then entered into the Excel. The analysis was carried out with the help of SPSS -17 W software program. All analyzed data were presented in the form of percentages. Chi-square tests were applied wherever applicable; Significance of differences was tested by Chi-square test. 'p' value less than 0.05 was considered statistically significant. 


\section{Objectives:-}

The purpose of this study was to examine the burden of regular disease and study the associated spectrum of morbidities in different urban slums of Varanasi district, Uttar Pradesh. Health seeking behavior of the respondents has been given higher preference. The specific study objectives of this study are

1. To assess the morbidity pattern of the urban slums population from the selected study area.

2. To determine the health seeking behavior of the present illness of the respondents.

\section{Results:-}

A total of 600 households were included in the study. Majority of the members of the household were belonged to age group15-29 1098 (28.89\%) followed by 0-4 with 936(25.4\%), 5-14 with 624(16.98\%), 30-44 with 517(14.07\%) and $45 \&$ above $498(13.5 \%)$ respectively. The mean age of the respondents found to be 32.41years .Out of total, $61.5 \%$ of the study population comprised of males. Majority of the respondents $569(94.8 \%)$ belonged to Hindu religion and $31(5.16 \%)$ of respondents were Muslim. Majority of respondents 516(86\%) were married and 84(14\%) found to be widow women in the study. Total illiterate male was recorded $228(86 \%)$ and female was $37(13.96 \%)$; also percentage of male respondents having qualification of primary and secondary with 77(98.7\%), 160(98.15\%) followed by high school \& above was 93(98.9\%). Amongst respondents were working on daily wages 222(37\%), own business 149(24.83\%), private jobs 65(13.83\%), government jobs 42(9.83\% respectively and 87(14.5\%). Only $87(14.5 \%)$ were found unemployed respondents. Among female respondents, percentage of unemployed was $33(37.33 \%)$.(Table 1). In all the demographic variables we found education \& occupation which was highly significant associated with respect to gender $(\mathrm{p}=0.001,0.01)$. One of the goals of the study was to determine the respondents' satisfaction towards type of treatment. To achieve this, we assess the satisfaction level of the respondents towards modern treatment and Ayurveda treatment and then their association with household characteristics was studied. Regarding overall satisfaction 15(71.4\%) of respondents were satisfied with the type of treatment i.e modern or ayurvedic medicine and also seen the significance association between type of treatment and gender distribution of the respondents. The details of overall satisfaction of treatment and household characteristics are provided in (Table 3).Similarly, an attempt was made to identify the association between health care system $\&$ household characteristics (Table3). The health care system was classified as government and private. In our study, only occupation of the respondents $(\mathrm{p}=0.0418)$ were found to be associated with health care system. The proportion of households who visited government hospitals was $273(45.5 \%)$ as against those who visited private hospitals $373(62.16 \%)$ during to illness. Majority of the respondents visited to government and private for availed the health facilities, the maximum number of visits was complaints of cold and cough 200(33.3\%) followed by due to pregnancy $166(27.67 \%)$, pain in abdomen 90(15\%), Pneumonia 42(7.00\%) and the least visits were due to gastro enteritis $21(3.50 \%)$. Over $35.3 \%$ of household of Binalaya slum received health care from private hospital due to pregnancy. Only $15 \%$ have sought health care from government health facilities. $25 \%$ household of Navabganj received the health care form the government cares during to viral, cough and cold illness. Table5

\section{Discussion:-}

The study was aimed to determine the morbidity pattern and health seeking behaviour of urban slums population in Varanasi city, Uttar Pradesh. The study found that socioeconomic status was the single most pervasive determinant of health seeking behaviour among the study population, overriding occupation and education of the household. These findings may not be generalized for all of Varanasi since the study was done only in on specific area of urban slums. In this study the measurement of health seeking behaviour was based on self-reported illness and action taken to seek treatment. In the study out of 600 household respondents, majority were belonging to 15-29 age groups 1098(30\%).Mean age of the respondents 32.41 years. The majority $516(86 \%)$ of the respondents were married and 84(14\%) widowed respectively. Similar findings were observed by Bukasa Parish, Makindye Division-Kampala ${ }^{7}$ and Jagdalpur Municipality, in Chhattisgarh state ${ }^{8}$. Most $462(44.9 \%)$ of the respondents were included in the age group of $\leq 10$ years. The mean age of urban slum respondents were 19.50 years $(\mathrm{SD}= \pm 17.929)$. The age distributions of the respondents were correspondent with the other studies conducted among the same population of railway line in Bukasa Parish, Makindye Division-Kampala [8] and the study done in urban population of Bangladesh ${ }^{9}$. Out of 600 household respondents, 569(94.83\%) were Hindu and only 31(5.16\%) were Muslim. BBS2009 found the similar statistics ${ }^{10}$. More than half $589(57.3 \%)$ of the slum respondents were illiterate and only 440 $(42.7 \%)$ were literate, which was not correspondent to the adult literacy rate of Bangladesh ${ }^{11}$.In our study found to be only 265(43.46\%) of the respondents illiterate rest of literate respectively . Out of 600 household seeking healths from modern medicine is very high when compared to Ayurveda and other system. Regarding morbidity, 511 $(49.6 \%)$ slum dwellers were sick during preceding 21 days. These findings were similar with the study conducted in 
rural population of Madhukhali Upazila of Faridpur District, Bangladesh ${ }^{12}$, Tamil Nadu, India ${ }^{13}$ and Bhosari, near Landevadi slum ${ }^{14}$. In the study, the frequently reported illnesses were respiratory diseases $257(25.0 \%)$, diseases of digestive system including diarrhea/ fever hepatitis /helminthiasis 233(22.6\%) and severe pain (Headache /chestpain/ Body ache) were 157(15.3\%). Hussain ${ }^{15}$ found the same disease pattern. Ahmed et al. noted the same findings in their study ${ }^{16}$, except fever, which was associated with the disease of all system of the body. In our study, highly reported disease was found to be viral cough and cold 200(33.3\%) followed by due to pregnancy problems $166(27.6 \%)$ of health care for slum population in Varanasi. Government medical college 141 (70.50\%) is the highest number of seeking health care services for the viral and cold in the study. The study indicates the preference of the respondents' private hospital/practitioner, while seeking health care than government hospitals during to illness. Some qualitative inputs have therefore been included in the study conducted by Zodpey $\mathrm{S}^{17}$ and Amitav Banerjee ${ }^{13}$. According to the reasons for not seeking treatment, majority $28(26 \%)$ of the respondents did not seek treatment due to lack of money and 27 (25\%) respondents waited for self-recovery. Another study done in an unregistered urban slum, Kaula Bandar (KB), in Mumbai, India, showed that clinic hours, often coincide with working hours, have lengthy waiting time, or are simply too far away and unaffordable ${ }^{14}$. Amitav Banerjee et al. also observed the similar findings ${ }^{13}$. In the study highly significant relationship was observed between occupation and education of the slum household with health seeking behavior $(\mathrm{P}=0.01$ and $\mathrm{P}=0.001)$ during illness. So, educational level and family income plays an important role in health seeking behaviour of surban slums household in this study.

\section{Conclusion:-}

The study shows that there, is urgent need to address the reasons for the improvements of the education status of the urban slums are recommended. Health education programmes should be conducted for the awareness of the health care services availed and also focuses on the importance of seeking early treatment and raising awareness during illness and taking drugs as prescribed. Further, in depth research should be conducted and the findings of the current study should be replicated to formulate policy measure to improve the overall scenario of the health facility in Varanasi, Uttar Pradesh. NGO's or health facilities can promote self-help groups or form Urban slums club or society where they can discuss their problems and NGOs can also increase awareness at community level.

Table1:- Socio demographic characteristic of households.

\begin{tabular}{|c|c|c|c|c|c|c|c|c|}
\hline S. N. & Background Characteristic & \multicolumn{2}{|c|}{ Male (\%) } & \multicolumn{2}{|c|}{ Female $(\%)$} & \multicolumn{2}{|c|}{ Total $(\%)$} & P-value \\
\hline \multicolumn{9}{|c|}{ Distribution of members in household according to age group } \\
\hline 1 & $0-4$ & 479 & 51.2 & 457 & 48.8 & 936 & 25.48 & \multirow{5}{*}{0.22} \\
\hline 2 & $5-14$ & 314 & 50.3 & 310 & 49.7 & 624 & 16.98 & \\
\hline 3 & $15-29$ & 494 & 45.0 & 604 & 55.0 & 1098 & 29.89 & \\
\hline 4 & $30-44$ & 333 & 64.4 & 184 & 35.6 & 517 & 14.07 & \\
\hline 5 & $45-90$ & 247 & 49.6 & 251 & 50.4 & 498 & 13.55 & \\
\hline \multicolumn{9}{|c|}{ Religion of households } \\
\hline 1 & Hindu & 528 & 92.79 & 41 & 7.20 & 569 & 94.83 & \multirow[t]{2}{*}{0.715} \\
\hline 2 & Muslim & 30 & 96.77 & 1 & 3.22 & 31 & 5.16 & \\
\hline \multicolumn{9}{|c|}{ Marital Status of households } \\
\hline 1 & Married & 513 & 99.41 & 3 & 0.58 & 516 & 86.00 & \multirow[t]{2}{*}{0.999} \\
\hline 2 & Widowed & 45 & 52.38 & 39 & 46.42 & 84 & 14.00 & \\
\hline \multicolumn{9}{|c|}{ Education of households } \\
\hline 1 & Illiterate & 228 & 86.03 & 37 & 13.96 & 265 & 44.16 & \multirow{4}{*}{0.001} \\
\hline 2 & Up to primary & 77 & 98.71 & 1 & 1.28 & 78 & 13.00 & \\
\hline 3 & Up to middle & 160 & 98.15 & 3 & 1.84 & 163 & 27.16 & \\
\hline 4 & High school \& above & 93 & 98.93 & 1 & 1.06 & 94 & 15.66 & \\
\hline \multicolumn{9}{|c|}{ Occupation of households } \\
\hline 1 & Not Working & 54 & 62.06 & 33 & 37.93 & 87 & 14.50 & \multirow{5}{*}{0.001} \\
\hline 2 & Daily Wages & 222 & 100 & 0 & 00.0 & 222 & 37.00 & \\
\hline 3 & Own Business & 148 & 99.32 & 1 & 0.67 & 149 & 24.83 & \\
\hline 4 & Private Job & 65 & 100 & 0 & 0.00 & 65 & 13.83 & \\
\hline 5 & Government Job & 39 & 66.10 & 3 & 33.89 & 42 & 9.83 & \\
\hline
\end{tabular}


Table 2:- Type of treatment satisfaction and its association with household characteristics.

\begin{tabular}{|c|c|c|c|c|c|c|c|}
\hline \multirow{2}{*}{$\begin{array}{l}\text { Background characteristics of } \\
\text { households } \\
\text { Sex }\end{array}$} & \multicolumn{4}{|c|}{ Type of treatment satisfaction } & \multicolumn{2}{|c|}{ Total $(\%)$} & \multirow[t]{2}{*}{ P-value } \\
\hline & \multicolumn{2}{|c|}{ Modern (\%) } & \multicolumn{2}{|c|}{ Ayurveda (\%) } & & & \\
\hline & 12 & 80.00 & 3 & 20.00 & 15 & 71.43 & \multirow[t]{2}{*}{0.031} \\
\hline Female & 5 & 83.33 & 1 & 6.67 & 6 & 28.57 & \\
\hline \multicolumn{7}{|c|}{ Religion } & \\
\hline Hindu & 15 & 78.94 & 4 & 21.05 & 19 & 90.47 & \multirow[t]{2}{*}{0.051} \\
\hline Muslim & 2 & 100 & 0 & 0.00 & 2 & 9.52 & \\
\hline \multicolumn{8}{|c|}{ Education } \\
\hline Illiterate & 93 & 93 & 7 & 7.00 & 100 & 70.42 & \multirow[t]{4}{*}{0.379} \\
\hline Up to primary & 16 & 94.11 & 1 & 5.88 & 17 & 11.97 & \\
\hline Up to middle & 13 & 86.66 & 2 & 13.33 & 15 & 10.56 & \\
\hline High school \& above & 10 & 100 & 0 & 0.00 & 10 & 7.04 & \\
\hline \multicolumn{8}{|c|}{ Occupation } \\
\hline Not Working & 61 & 91.04 & 6 & 8.96 & 67 & 76.14 & \multirow[t]{5}{*}{0.235} \\
\hline Daily Wages & 8 & 88.89 & 1 & 11.11 & 9 & 10.23 & \\
\hline Own Business & 7 & 77.78 & 2 & 22.22 & 9 & 10.23 & \\
\hline Private Job & 1 & 100.00 & 0 & 0.00 & 1 & 1.14 & \\
\hline Government Job & 2 & 100.00 & 0 & 0.00 & 2 & 2.27 & \\
\hline
\end{tabular}

Table 3:- Health care system its association with respondents characteristics.

\begin{tabular}{|c|c|c|c|c|c|c|c|}
\hline \multirow{3}{*}{$\begin{array}{l}\begin{array}{l}\text { Background Characteristics of } \\
\text { household }\end{array} \\
\text { Sex } \\
\text { Male }\end{array}$} & \multicolumn{4}{|c|}{ Health care system } & \multicolumn{2}{|l|}{ Total } & \multirow{3}{*}{$\begin{array}{l}\text { P value } \\
0.428\end{array}$} \\
\hline & \multicolumn{2}{|c|}{ Government } & \multicolumn{2}{|c|}{ Private } & & & \\
\hline & 225 & 40.25 & 334 & 59.75 & 559 & 93.17 & \\
\hline Female & 19 & 46.34 & 22 & 53.66 & 41 & 6.83 & \\
\hline \multicolumn{8}{|l|}{ Religion } \\
\hline Hindu & 231 & 40.81 & 335 & 59.19 & 566 & 94.33 & 0.0873 \\
\hline Muslim & 9 & 26.47 & 25 & 73.53 & 34 & 5.67 & \\
\hline \multicolumn{8}{|l|}{ Education } \\
\hline Illiterate & 96 & 39.02 & 150 & 60.98 & 246 & 41.00 & \multirow[t]{4}{*}{0.683} \\
\hline Up to primary & 42 & 40.38 & 62 & 59.62 & 104 & 17.33 & \\
\hline Up to middle & 80 & 47.06 & 90 & 52.94 & 170 & 28.33 & \\
\hline High school \& above & 30 & 37.50 & 50 & 62.50 & 80 & 13.33 & \\
\hline \multicolumn{8}{|l|}{ Occupation } \\
\hline Not Working & 44 & 31.65 & 95 & 68.35 & 139 & 23.17 & \multirow[t]{5}{*}{0.0418} \\
\hline Daily Wages & 95 & 48.72 & 100 & 51.28 & 195 & 32.50 & \\
\hline Own Business & 78 & 55.32 & 63 & 44.68 & 141 & 23.50 & \\
\hline Private Job & 28 & 37.84 & 46 & 62.16 & 74 & 12.33 & \\
\hline Government Job & 29 & 56.86 & 22 & 43.14 & 51 & 8.50 & \\
\hline \multicolumn{8}{|l|}{ Distance (in meter) } \\
\hline $0-1000$ & 68 & 54.40 & 57 & 45.60 & 125 & 20.88 & \multirow[t]{4}{*}{0.356} \\
\hline $1000-2000$ & 77 & 46.11 & 9 & 53.89 & 167 & 27.83 & \\
\hline $2000-3000$ & 130 & 76.02 & 3 & 23.98 & 171 & 28.50 & \\
\hline 3000-above & 70 & 51.09 & 0 & 48.91 & 137 & 22.83 & \\
\hline
\end{tabular}

Table 4:- Visit of individuals to public and private health care delivery system.

\begin{tabular}{|l|c|c|c|c|c|c|}
\hline Purpose of visit & \multicolumn{2}{|c|}{ Government-273 (\%) } & \multicolumn{2}{|c|}{ Private-373(\%) } & \multicolumn{2}{c|}{ Total (\%) } \\
\hline Due to Pregnancy & 68 & 40.96 & 98 & 59.04 & 166 & 27.67 \\
\hline
\end{tabular}




\begin{tabular}{|l|c|c|c|c|c|c|}
\hline Viral \& cold cough & 59 & 29.50 & 141 & 70.50 & 200 & 33.33 \\
\hline Pneumonia & 30 & 71.43 & 12 & 28.57 & 42 & 7.00 \\
\hline Pain in Abdomen & 70 & 77.78 & 20 & 22.22 & 90 & 15.00 \\
\hline Gastro Enteritis & 10 & 47.62 & 11 & 52.38 & 21 & 3.50 \\
\hline Others & 36 & 44.44 & 45 & 55.56 & 81 & 13.50 \\
\hline
\end{tabular}

Table 5:- Utilization of Health Care Delivery System according to urban slums.

\begin{tabular}{|c|c|c|c|c|c|c|c|c|c|}
\hline $\begin{array}{l}\text { Health Seeking } \\
\text { Behavior } \\
\text { (Households) }\end{array}$ & facility & $\begin{array}{r}\text { Badi } \\
\text { Gaiby }\end{array}$ & $\begin{array}{r}\text { Binaya } \\
\text { ka }\end{array}$ & $\begin{array}{r}\text { Chaiti } \\
\text { pur }\end{array}$ & $\begin{array}{r}\text { Karau } \\
\text { ndi }\end{array}$ & $\begin{array}{r}\text { Navab } \\
\text { Ganj }\end{array}$ & $\begin{array}{r}\text { Ranip } \\
\text { ur }\end{array}$ & $\begin{array}{r}\text { Tulsip } \\
\text { ur }\end{array}$ & $\begin{array}{c}\text { Total } \\
(\%)\end{array}$ \\
\hline \multirow[t]{2}{*}{ Due to Pregnancy } & $\begin{array}{l}\text { Govern } \\
\text { ment }\end{array}$ & $5(9.1)$ & $\begin{array}{r}77 \\
(12.7)\end{array}$ & $\begin{array}{r}8 \\
(14.5)\end{array}$ & $\begin{array}{r}13 \\
(23.6)\end{array}$ & $3(5.5)$ & $\begin{array}{r}14 \\
(25.5)\end{array}$ & $\begin{array}{r}8 \\
(14.5)\end{array}$ & $\begin{array}{r}55 \\
(13.6)\end{array}$ \\
\hline & Private & $\begin{array}{r}10 \\
(14.7)\end{array}$ & $3(4.4)$ & $\begin{array}{r}24 \\
(35.3)\end{array}$ & $5(7.4)$ & $9(13.2)$ & $\begin{array}{r}10 \\
(14.7)\end{array}$ & $\begin{array}{r}7 \\
(10.3)\end{array}$ & $\begin{array}{r}68 \\
(16.8)\end{array}$ \\
\hline \multirow[t]{2}{*}{ Viral \& cold cough } & $\begin{array}{l}\text { Govern } \\
\text { ment }\end{array}$ & $5(14.3)$ & $0(0.0)$ & $\begin{array}{r}11 \\
(0.3)\end{array}$ & $9(0.2)$ & $6(0.5)$ & $1(0.1)$ & $3(0.3)$ & $\begin{array}{r}35 \\
(8.6)\end{array}$ \\
\hline & Private & $10(8.0)$ & $\begin{array}{r}21 \\
(16.8)\end{array}$ & $\begin{array}{r}24 \\
(19.2)\end{array}$ & $\begin{array}{r}15 \\
(12.0)\end{array}$ & $14(11.2)$ & $\begin{array}{r}25 \\
(20.0)\end{array}$ & $\begin{array}{r}16 \\
(12.8)\end{array}$ & $\begin{array}{r}125 \\
(30.9)\end{array}$ \\
\hline \multirow[t]{2}{*}{ Pneumonia } & $\begin{array}{l}\text { Govern } \\
\text { ment }\end{array}$ & $0(0.0)$ & $0(0.0)$ & $0(0.0)$ & $\begin{array}{r}3 \\
(100.0)\end{array}$ & $0(0.0)$ & $0(0.0)$ & $0(0.0)$ & $3(0.7)$ \\
\hline & Private & $1(9.1)$ & $\begin{array}{r}4 \\
(36.4)\end{array}$ & $\begin{array}{r}3 \\
(27.3)\end{array}$ & $\begin{array}{r}2 \\
(18.2)\end{array}$ & $0(0.0)$ & $0(0.0)$ & $1(9.1)$ & $\begin{array}{r}11 \\
(2.7)\end{array}$ \\
\hline \multirow[t]{2}{*}{ Pain in Abdomen } & $\begin{array}{l}\text { Govern } \\
\text { ment }\end{array}$ & $0(0.0)$ & $0(0.0)$ & $\begin{array}{r}2 \\
(33.3)\end{array}$ & $\begin{array}{r}4 \\
(66.7)\end{array}$ & $0(0.0)$ & $0(0.0)$ & $0(0.0)$ & $6(1.5)$ \\
\hline & Private & $3(20.0)$ & $1(6.7)$ & $\begin{array}{r}6 \\
(40.0)\end{array}$ & $\begin{array}{r}2 \\
(13.3)\end{array}$ & $0(0.0)$ & $0(0.0)$ & $\begin{array}{r}3 \\
(20.0)\end{array}$ & $\begin{array}{r}15 \\
(3.7) \\
\end{array}$ \\
\hline \multirow[t]{2}{*}{ Gastro Enteritis } & $\begin{array}{l}\text { Govern } \\
\text { ment }\end{array}$ & $1(10.0)$ & $0(0.0)$ & $\begin{array}{r}5 \\
(50.0) \\
\end{array}$ & $\begin{array}{r}4 \\
(40.0) \\
\end{array}$ & $0(0.0)$ & $0(0.0)$ & $0(0.0)$ & $\begin{array}{r}10 \\
(2.5) \\
\end{array}$ \\
\hline & Private & $1(9.1)$ & $\begin{array}{r}3 \\
(27.3)\end{array}$ & $\begin{array}{r}2 \\
(18.2)\end{array}$ & $\begin{array}{r}4 \\
(36.4)\end{array}$ & $1(9.1)$ & $0(0.0)$ & $0(0.0)$ & $\begin{array}{r}11 \\
(2.7)\end{array}$ \\
\hline \multirow[t]{2}{*}{ Others } & $\begin{array}{l}\text { Govern } \\
\text { ment }\end{array}$ & $2(6.7)$ & $\begin{array}{r}4 \\
(13.3) \\
\end{array}$ & $\begin{array}{r}8 \\
(26.7) \\
\end{array}$ & $\begin{array}{r}10 \\
(33.3) \\
\end{array}$ & $3(10.0)$ & $1(3.3)$ & $2(6.7)$ & $\begin{array}{r}30 \\
(7.4) \\
\end{array}$ \\
\hline & Private & $7(19.4)$ & $\begin{array}{r}5 \\
(13.9)\end{array}$ & $\begin{array}{r}8 \\
(22.2)\end{array}$ & $\begin{array}{r}5 \\
(13.9)\end{array}$ & $5(13.9)$ & $0(0.0)$ & $\begin{array}{r}6 \\
(16.7)\end{array}$ & $\begin{array}{r}36 \\
(8.9)\end{array}$ \\
\hline
\end{tabular}

\section{Reference:-}

1. T Kidokoro, J Okata, S. Matsumara . N. Shima Vulnerable Cities Relities, Innovation and Strategies .cURT

2. Census 2011Registrar General \& Census Commissioner, India Ministry of home affair, Government of India

3. Ahmed SM, Chowdhury M, Bhuiya A. Healthcare seeking behaviour of BRAC member and non-member households: evidence from Matlab, Bangladesh. BRACICDDR, B Joint Research Project Dhaka, Bangladesh: Working Paper Number, 2,1-20.

4. Chowdhury S, Hossain SA, Halim A. Assessment of quality of care in maternal and newborn health services available in public health care facilities in Bangladesh. Bangladesh Med Res Counc Bull 2009; 35:53-6.

5. Shaikh BT, Hatcher J. Health seeking behavior and health service utilization in Pakistan: challenging the policy makers. Public Health 2005; 27:49-4.

6. Impact assessment of health care for slum dwellers. Prepared by, MRC Mode Limited. December, 2009.

7. Kirabira P, Nagaddya T. Situational Analysis of the health status of the slum dwelling population along the railway line in Bukasa Parish, Makindye Division-Kampala, 2012. Website: www.ihsu.ac.ug.

8. Bandela Anil Prasad. Urban Sanitation: Health Challenges of the Urban Poor. Research Journal of Family, Community and Consumer Sciences. 2013; 1(3):1-6. Available online at: www.isca.in

9. Islam TAA, Baqui MA, Reinke AH, Black W, Robert E. Health and demographic profile of urban population of Bangladesh. ICDDR, B special publication no, 1996, 47.

10. Bangladesh Bureau of Statistics. 2008 Statistical Yearbook of Bangladesh. Dhaka: Planning Division, Ministry of Planning, Government of the People's Republic of Bangladesh, 2009. 
11. Report of Sample Vital Registration System (SVRS) Bangladesh Bureau of Statistics (BBS). Dhaka: Planning Division, Ministry of Planning, Government of the People's Republic of Bangladesh, 2008.

12. Banerjee A, Bhawalkar JS, Jadhav SL. Access to Health Services Among Slum Dwellers in an Industrial Township and Surrounding Rural Areas: A Rapid Epidemiological Assessment. J Family Med Care. 2012; 1(1):20-26.

13. Rajiv S, Prabhu S, Bhuvaneshwari T, Sindhu KNC, Ajjampur SSR, Muliyil J et al. Burden of childhood diseases and malnutrition in a semi-urban slum in southern India. BMC Public Health, 2013, 13:87.

14. Hussain S, Malik F, Hameed A, Ahmad S, Riaz H. Exploring health seeking Behavior, medicine use and selfmedication in urban and rural Pakistan. Southern Med Review 2010, 3(2):32-34.

15. Ahmed SM, Adams AM, Chowdhury M, Bhuiya A. Gender, socioeconomic development and health-seeking behaviour in Bangladesh. Social Science \& Medicine 2000; 51:361-71.

16. Marinka van der H, Annamarie K, Minrie G. Differences in health care seeking behaviour between rural and urban communities in South Africa. International Journal for Equity in Health. 2012, 11:31.

17. Zodpey S. Can primary health care reinvent itself to impact health care utilization? Indian J Public Health. 2012; 1(1):20-26. 